\title{
Tissue culture of two medicinal trees native to Japan
}

\author{
Katsuaki Ishii, Naoki Takata, Manabu Kurita, Toru Taniguchi \\ From IUFRO Tree Biotechnology Conference 2011: From Genomes to Integration and Delivery \\ Arraial d Ajuda, Bahia, Brazil. 26 June - 2 July 2011
}

Wadatsuminoki (Nothapodytes amamianus) is an endangered tree species observed in only Amami Oshima Island located in southern part of Japan. According to the Red list published by Ministry of Environment, it is classified as 1A (Critically endangered) and naturally remaining number is only 20 . It contains camptotesin which is used for anti-cancer drugs. Kagikazura (Uncaria rhynchophylla) is an medicinal tree species observed widely in Japan and China. It contains alkaloids (rhynchophylline, iso-rhynchophylline, hirstine and so on) which are good for remedy of high blood pressure and dementia. For the purpose of micropropagation and development of basis of useful substance production by cell culture as well as conservation of endangered species, tissue culture procedure was developed for those two species.

Excised shoots of 2 years old seedling of Wadatsuminoki rooted in the $1 / 2 \mathrm{DCR}$ medium containing $3 \mathrm{~g} / \mathrm{l}$ activated charcoal powder. Newly shoots were induced from in vitro root segments subcultured to 1/2MS medium containing $2 \mathrm{uM}$ BAP. This cycle can be used for micropropagation of Wadatsuminoki. We have succeeded in micropropagation by tissue culture of Wadatsuminoki (Figure 1). Callus proliferation from stem or root segments was observed on the 1/2LP medium containing 0.5uM BAP and $1 \mathrm{uM} 2,4-\mathrm{D}$, this subculture cell line may be used for the possible production of secondary metabolites in vitro.

Shoots were induced from stem spine (thorn) of Kagikazura in the $1 / 2 \mathrm{MS}$ medium containing BAP or Zeatin. Regenerated plants were obtained by rooting of these shoots on $1 / 2 \mathrm{MS}$ medium containing $1 \mathrm{uM}$ IBA. Callus induced around the stem segments were continuously subcultured in the fresh $1 / 2 \mathrm{LP}$ medium containing 0.5

\footnotetext{
* Correspondence: katsuaki@ffpri.affrc.go.jp

Forest Bio-research Center, Forestry and Forest Products Research Institute, Japan
}

() 2011 Ishii et al; licensee BioMed Central Ltd. This is an open access article distributed under the terms of the Creative Commons Attribution License (http://creativecommons.org/licenses/by/2.0), which permits unrestricted use, distribution, and reproduction in any medium, provided the original work is properly cited.
uM BAP and 1 uM 2, 4-D. These cell lines can be used for the possible secondary metabolite production and for breeding by somaclonal variation or genetic engineering.

Published: 13 September 2011

doi:10.1186/1753-6561-5-S7-P137

Cite this article as: Ishii et al:: Tissue culture of two medicinal trees native to Japan. BMC Proceedings 2011 5(Suppl 7):P137.

Submit your next manuscript to BioMed Central and take full advantage of:

- Convenient online submission

- Thorough peer review

- No space constraints or color figure charges

- Immediate publication on acceptance

- Inclusion in PubMed, CAS, Scopus and Google Scholar

- Research which is freely available for redistribution

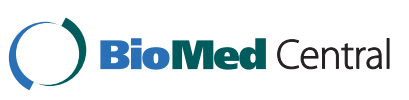

